\title{
TUMURUNE HAPSARI
}

\author{
Oleh : Fetri Ana Rachmawati \\ Pembimbing tugas akhir ( Dindin Heryadi, M.Sn dan Dra. Sri Hastuti, M.Hum ) \\ Jurusan Tari, Fakultas Seni Pertunjukan Institut Seni Indonesia Yogyakarta \\ Alamat Email: fetrirachmawati15@gmail.com
}

\section{RINGKASAN}

Kesenian Sintren merupakan kesenian yang hadir di wilayah pantai utara salah satunya terdapat di Kabupaten Indramayu kecamatan Haurgeulis. Terciptanya kesenian Sintren dari cerita percintaan antara Sulasih dan Raden Sulandono.

Karya ini diberi judul Tumurune Hapsari, Rangsang awal dalam karya ini yakni rangsang ide kemudian rangsang kinestetik. Tema yang dipilih dalam karya ini yakni koreografi tari yang bersumber dari sikap "Ikhlas" penari sintren yang bernama Ade Nuriya ketika menari. Makna "Ikhlas" dalam penafsiran penata diartikan bahwa tubuh yang bergerak secara kinestetis tanpa ada pemaksaan, mengalir dengan lembut, juga bergerak secara tiba-tiba dan menghentak, semuanya dibungkus dengan suasana yang magis. Komposisi yang digunakan dalam karya ini yakni dengan bentuk dramatik.

Karya ini ditarikan oleh 7 orang penari perempuan dewasa dan 10 penari perempuan anakanak. Karya ini menggunakan properti kurungan. Musik iringan yang digunakan bergaya Indramayuan.

Kata Kunci : Penari sintren, Ikhlas, dramatik.

\section{ABSTRACT}

Art is an art Sintren The Present in the North Coast Region Only prayers are in Indramayu districts Haurgeulis. The creation of art Sintren Of Love story between Sulasih And Raden Sulandono.

This Creation entitled Tumurune Hapsari, Early Stimulation hearts work of the singer Stimulate ideas then kinesthetic stimuli. The theme chosen hearts that dance choreography work of singer Yang sourced from attitude "Sincere" sintren dancer wich name is Ade Nuriya when dancing. Meaning "Sincere" the interpretation means that the stylists are kinesthetic body moving 
without coercion, Flowing with Gentle, Moving Also Operates Emergent And stomping, all wrapped in a magical atmosphere. The composition used hearts that work with Forms dramatic singer.

Singer works by Women dancers danced orangutan 7 adults and 10 dancers Female Children. In the work of singer using confinement property. The musical accompaniment is used Indramayuan style.

This creation danced by 7 dancers female adult and 10 dancer female children. In this work using the properties of confinement. Musical accompaniment style used Indramayuan

Keywords: Dancer sintren, sincere, dramatic.

\section{PENDAHULUAN}

Indramayu merupakan kabupaten di Jawa Barat yang secara geografis berada di daerah pesisir pantai utara, diapit oleh beberapa kabupaten yaitu Subang, Cirebon, Majalengka, dan Kuningan. Letak geografis Indramayu yang berada di kawasan pantai utara maka kabupaten Indramayu memiliki kebudayaan, adat istiadat, dan kesenian yang tidak jauh berbeda dengan daerah-daerah yang berada di kawasan pantai utara lainnya seperti Cirebon dan Pekalongan salah satu kesenian yang dimiliki oleh daerah-daerah ini yaitu sintren.

Sintren berasal dari kata sintiran atau santrian yaitu sejenis permainan rakyat yang mengandung unsur-unsur magis. ${ }^{1}$

1 Dede Wahidin. 2005. Deskpripsi kesenian Cirebon, Kementrian Kebudayaan dan Pariwisata, Jakarta, p. 28.
Keistimewaan kesenian ini adalah terjadinya peristiwa Kesurupan (trance) pada penarinya. Kesurupan berasal dari kata surup yang memiliki arti kerasukan (setan, roh), orang yang "kesurupan" biasanya bertindak yang aneh-aneh.

Menurut tradisi lisan tarian Sintren ini bersumber dari sebuah cerita cinta kasih Raden Sulandono dan kekasihnya Sulasih. Raden Sulandono merupakan putra dari Ki Bahurekso bupati Kendal yang pertama hasil pernikahannya dengan Dewi Rantamsari yang dijuluki Dewi Lanjar. Pertunjukan sintren diperkirakan lahir sebelum islam masuk ke daerah Indramayu dan Cirebon. ${ }^{2}$ Kisah kasih antara Sulasih dan Raden Sulandono tidak

2 Dede Wahidin. 2005. deskpripsi kesenian Cirebon, Kementrian Kebudayaan dan Pariwisata, Jakarta, p. 28. 
mendapatkan restu dari $\mathrm{Ki}$ Bahurekso ayahanda Dari Raden Sulandono karena Sulasih merupakan rakyat biasa.

Adapun bentuk pertunjukan Sintren diawali dengan pra pertunjukan, saat dimulainya tabuhan gamelan sebagai tanda akan dimulainya pertunjukan Sintren ditabuh lagu-lagu dangdut pantura untuk mengumpulkan massa. Tahap paling pokok dalam pertunjukan Sintren yakni inti pertunjukan, diawali dengan doa yang dipimpin pawang kemudian diikuti oleh penari sintren, setelah itu penari sintren jatuh tidak sadarkan diri. Tangan dan tubuh mulai dari leher sampai ke ujung ibu jari kaki penari sintren diikat dengan tali oleh pawang. Kemudian penari dimasukkan ke dalam kurungan bersama busana tari yang sebelumnya telah dilipat terpisah dari ikatan penari sintren.

Pertunjukan Sintren disajikan pada waktu sunyi dan menurut kepercayaan masyarakat lebih utama lagi kalau dipentaskan pada malam kliwon. Tempat yang biasanya digunakan pertunjukan Sintren adalah arena terbuka. yaitu berupa arena pertunjukan yang tidak terlihat batas antara penonton dengan penari sintren maupun pendukungnya.

Pendukung pertunjukan Sintren terdiri dari 1 pawang, dayang cantik biasanya berjumlah 4 orang perempuan atau 7, pengiring musik/tembang terdiri dari 3 orang perempuan sebagai penyanyi, 1 grup penabuh gamelan yang berjumlah kurang lebih 10 orang, dan penari sintren yang menjadi daya tarik paling utama dalam pertunjukan sintren.

Sorotan utama dalam kesenian Sintren yaitu penarinya harus seorang anak perempuan yang masih suci, mungkin hal ini juga yang menjadikan penari sintren mempunyai daya tarik bagi penonton. Sebelum menjadi penari sintren siapapun peminatnya diwajibkan menempuh beberapa tahapan laku spiritual. Calon penari sintren harus sanggup puasa/tirakat senin kamis selama 40 hari, dan juga diwajibkan untuk mandi kembang. Jika seluruh persyaratan itu mampu dijalankan dengan baik, sungguh-sungguh dan ikhlas sesuai dengan kepercayaan mereka, maka dipercaya pertunjukan akan aman dan sukses.

Dari banyak tahapan-tahapan untuk menjadi penari sintren yang dipaparkan, maka penata tertarik untuk mendalami hal itu, penata melakukan wawancara terhadap penari sintren. Wawancara yang dilakukan pada tanggal 9 Juli 2016 di Desa Kertanegara kecamatan Haurgeulis, Kabupaten Indramayu, pada saat diadakannya pertunjukan sintren di salah satu rumah warga yang bernama pak Suki. Wawancara dilakukan terhadap penari sintren yang bernama Ade Nuriya berumur 16 tahun.

Ade sudah menjadi penari Sintren selama 6 tahun dengan bergabung dengan grup Kelana Muda yang berdomisili di Desa 
Kertanegara blok 21 Kecamatan Haurgeulis Kabupaten Indramayu. Dengan polos Ade Nuriya menyebutkan bahwa kunci utama untuk menjadi penari sintren adalah ikhlas. Yakni ikhlas dalam artian sikap rela tubuhnya dirasuki oleh roh lain yang menyebabkan tubuhnya digerakkan oleh roh lain. Selain Ade Nuriya penata juga mewawancarai yang dulunya seorang penari sintren yang bernama Nur Azizah. Dia menceritakan pengalaman bagaimana ketika dulu dia menjadi seorang penari sintren ikhlas tubuhnya dirasuki roh lain. Awal mulanya Nur Azizah merasa ikhlas setiap pementasan Sintren tubuhnya dipinjam oleh roh lain. Nur Azizah juga menyampaikan ketika pementasan Sintren sering diminta untuk pentas, sehingga Nur merasa kelelahan.

Dari pemaparan permasalahan yang timbul yakni bagaimana beberapa penari sintren yang memiliki rasa ikhlas. Hal tersebut yang menarik penata untuk membuat sebuah karya berbentuk koreografi tari yang bersumber dari sikap "ikhlas" yang berbeda antar penari sintren. Makna "ikhlas" dalam penafsiran penata dapat diartikan atau dianalogikan dengan tubuh yang bergerak secara kinestetis tanpa ada pemaksaan. Dalam koreografi setiap penari bergerak dengan keinginannya masing-masing, ada yang bergerak mengikuti alunan musik ada juga yang bergerak melawan alunan musik menurut keinginan tubuhnya. Untuk memperlihatkan bagaimana perbedaan keihlasan penari sintren. Namun adegan itu tentu dihadirkan hanya pada adegan tertentu yang menggambarkan keikhlasan penari sintren.

Proses pencarian gerak penata mengambil beberapa motif dari tari Randu Kentir. Koreografi ini mengeksplor kurungan ayam untuk menjadi properti tari karena kurungan ayam juga sebagai identitas kesenian Sintren. Karya ini dikomposisikan oleh penata dengan memilih 7 penari putri. Penata memilih 7 penari karena kebutuhan visualisasi dan komposisi serta angka 7 memiliki arti dari jumlah bidadari yang turun untuk memasuki tubuh penari Sintren.

\section{PEMBAHASAN}

\section{A. Proses Penciptaan}

\section{Rangsang Awal}

Rangsang awal dalam karya ini yakni rangsang gagasan (idesional) pada saat penata melihat pertunjukan Sintren, selain rangsang ide berikutnya adalah rangsang dalam garapan tari ini adalah rangsang kinestetik. Gerak atau frase gerak tertentu berfungsi sebagai rangsang kinestetis. ${ }^{3}$ Melalui rangsang kinestetik penata tertarik dengan motif gerak yang terdapat dalam tari Randu Kentir.

${ }^{3}$ Jacqueline Smith. 1976. Dance Compositio: A Practical Guide for Teacher.1976. Diterjemahkan Ben Suharto.1985. Komposisi Tari: Sebuah Petunjuk Asli Bagi Guru, Ikalasti, yogyakarta, p. 20-21. 


\section{Tema Tari}

Berdasarkan rangsang tari tema yang dipilih dalam karya ini adalah "keikhlasan penari sintren yang berbeda-beda". Dari tema tersebut akan diaplikasikan ke dalam karya dengan bentuk dramatik dan menurut imajinasi penata dalam mengkreasikan pertunjukan Sintren demi kepentingan sebuah pertunjukan.

\section{Judul Tari}

Dalam karya ini judul yang diberikan ialah Tumurune Hapsari. Tumurune dalam bahasa Jawa memiliki arti turun dan hapsari mempunyai arti bidadari. Jika digabungkan Tumurune Hapsari memiliki arti turunnya para bidadari dari singgasananya dan memasuki tubuh seorang penari Sintren.

\section{Bentuk dan Cara Ungkap}

Tipe tari yang digunakan dalam karya ini yakni tipe tari dramatik, karena memusatkan perhatian pada sebuah kejadian atau suasana yang tidak menggelarkan ceritra. $^{4}$ Cara penyajian Pada karya ini menggunakan mode penyajian representasional dan nonrepresentasional ( simbolik). Dalam karya ini selain penonton menyaksikan penyajian yang disajikan, juga mengajak

${ }^{4}$ Jacqueline smith. 1976. Dance Composition A Practicecal Guide for Teacher. Diterjemahkan Ben Suharto. 1985. Komposisi Tari: Sebuah Pentunjuk Prakti Bagi Guru. Terjemahan Ben Suharto, Ikalasti, Ikalasti, p. 27. emosi penonton untuk merasakan konflik yang terdapat dalam karya tari ini.

\section{Gerak}

Motif gerak yang terdapat pada tari Randu Kentir yang menjadi acuan utama dalam proses pencarian dan pengembangan gerak, penata mengambil beberapa motif dalam tari Randu Kentir. Gerak lainnya yang menjadi media dalam koreografi ini gerak pinggang pinggul dan keupat yang biasanya dilakukan oleh penari Sintren ketika trance.

\section{Penari}

Dalam koreografi ini penata melibatkan 7 penari perempuan dewasa, penata melibatkan 7 penari perempuan sebagai lambang 7 bidadari yang turun untuk masuk ke dalam tubuh penari sintren. Penata juga menggunakan 10 penari anak-anak yang berusia 11-15 tahun sebagai simbol bahwa penari Sintren yang sebenarnya berkisar pada usia 11-17 tahun. Adapun penggunaan 10 penari anak-anak tidak melambangkan suatu apapun karna hanya semata-mata untuk kepentingan komposisi.

\section{Musik Tari}

Pada musik iringan tari Tumurune Hapsari bernuansa musik khas Indramayu. Alat musik yang digunakan dalam penggarapan karya tari ini disesuaikan dengan tema. Dalam karya ini iringan tari bersifat 
ilustratif dan ritmis dengan pengambaran suasana magis.

\section{Rias dan Busana}

Karya ini menggunakan konsep rias korektif, sebagai visualisasi dari perempuan remaja yang cantik. Kostum pada baju akan menggunakan warna merah, simbol warna terkuat dan paling menarik perhatian, bersifat agresif lambang primitif. Warna ini diasosiasikan sebagai darah, marah, berani, seks, bahaya, kekuatan, kejantanan, kebahagiaan. $^{5}$ Keterkaitan warna tersebut dalam konsep karya ini melambangkan keceriaan dan hal mistis.

\section{Tata rupa pentas}

Karya ini menggunakan properti kurungan ayam yang diselimuti kain, properti ini digunakan karena kesenian sintren menggunakan properti utama sebuah kurungan ayam.

\section{Pencahayaan}

Karya ini mengggunakan gobo yang bebentuk gambar perempuan untuk melambangkan sang bidadari yang turun ke bumi untuk memasuki tubuh sang penari Sintren.

\section{B. Realisasi Karya}

Observasi dan wawancara secara langsung kepada narasumber merupakan tahap untuk mendapatkan informasi yang dibutuhkan dalam penggarapan karya tari ini.

\section{Rias dan Busana}

Pemilihan rias wajah dalam karya tari ini menggunakan makeup korektif karena dalam karya ini menceritakan seorang sosok perempuan yang masih belia. Tata rambut menggunakan sanggul yang biasa disebut masyarakat umum sanggul $B C L$ kreasi. Kemudian diberi tambahan hiasan kepala yang diberi untaian imitasi bunga melati, alasan kenapa menggunakan untaian bunga melati unutuk memberi kesan magis.

Dalam karya ini penata menggunakan dua busana yang berbeda, karena dalam kesenian sintren sendiri terdapat adegan berganti busana. Busana yang pertama yang digunakan menggunakan kostum atasan berwarna hijau, bawahan celana berwawrna hijau dan rok berwarna merah. Penggunaan warna hijau melambangkan muda, dalam karya ini dapat diartikan penari sintren yang berusia masih muda. Warna merah melambangkan keberanian seorang penari sintren.

\footnotetext{
5 Sulasmi Darmaprawira. 2008. WARNA, ITB, Bandung, p. 45.
} 


\section{JOGED}

ISSN: $1858-3989$

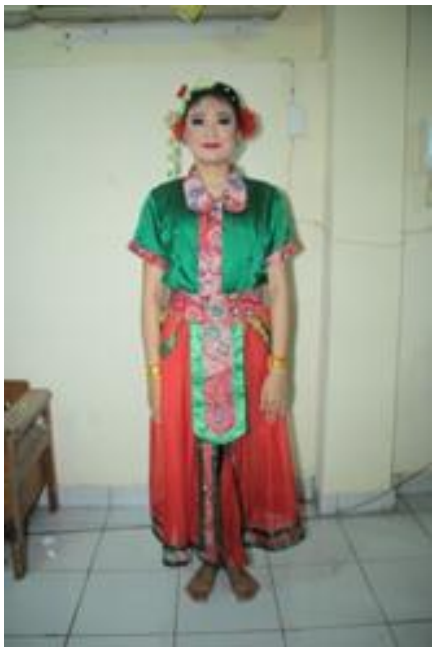

Gambar 1. Kostum pertama tampak depan yang digunakan pada adegan 1 dan adegan 2. (doc. Ari Kusuma. 2017)

Busana kedua menggunakan atasan berwarna putih digabung dengan batik dengan motif mega mendung dan bawahan rok berwarna putih.

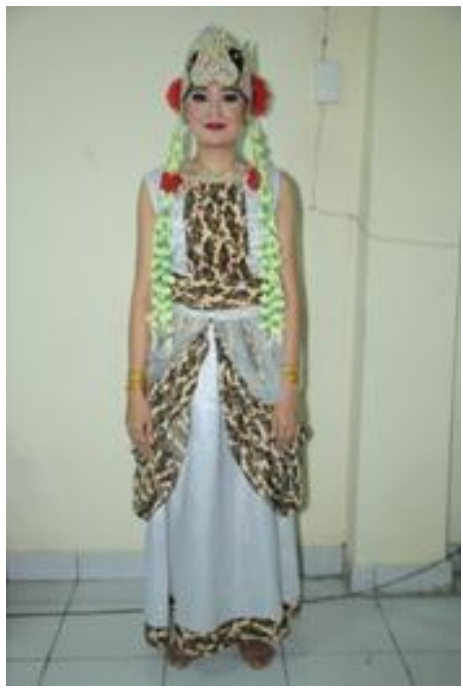

Gambar 2. Kostum kedua tampak depan yang digunakan pada adegan 3 dan ending. (doc. Ari Kusuma 2017)
Fetri Ana Rachmawati (JURNAL TUMURUNE HAPSARI)

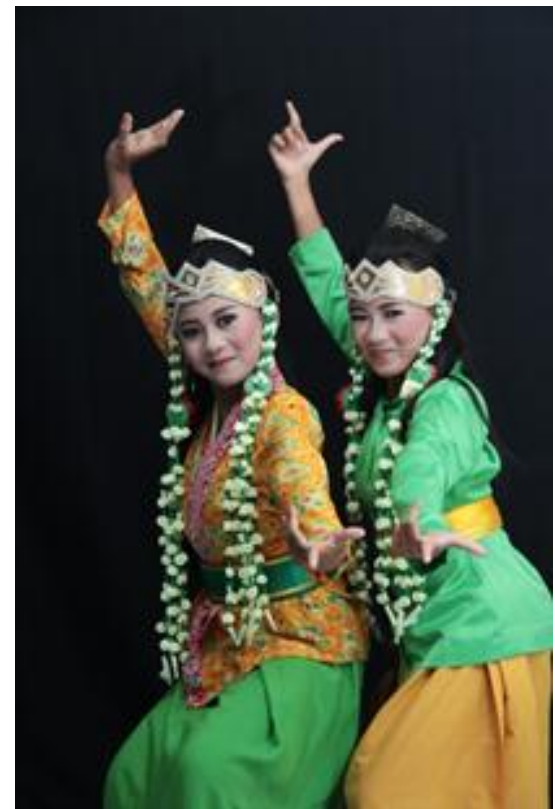

Gambar 3. Kostum penari anak-anak tampak samping. (doc. Ari Kusuma. 2017)

2. Proses Penata Tari dengan Tim Artistik

Penata tari mempercayakan tatanan artistik pada Cahyo atau biasa dipanggil mas Cahyo. Dalam karyaini penata tari menggunakan properti kurungan yang sudah dirubah bentuknya.

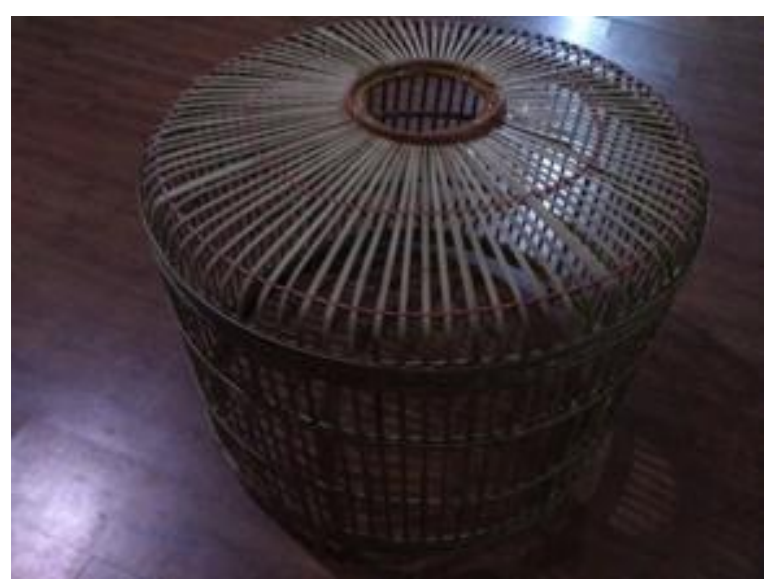

Gambar 4. Properti kurungan ayam. (doc. Fetri Ana Rachmawati. 2016 ) 


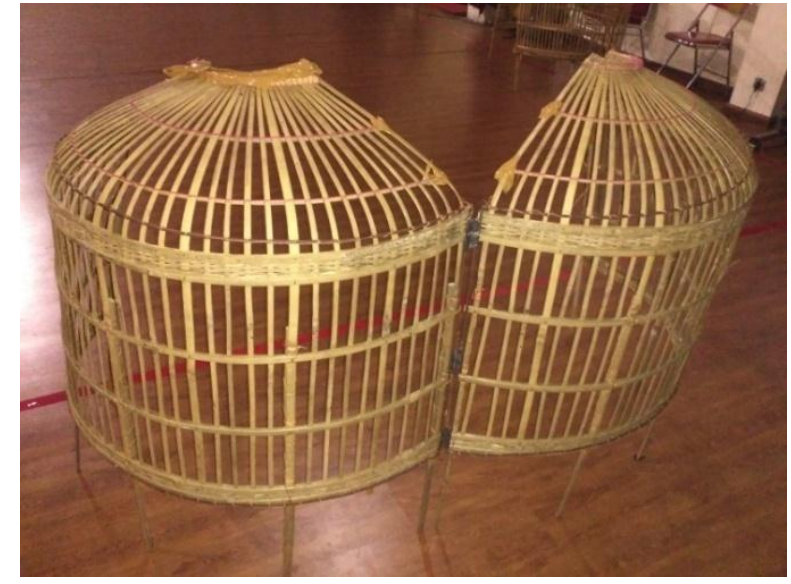

Gambar 5. Inovasi properti kurungan ayam (doc. Fetri Ana Rachmawati. 2016)

\section{Evaluasi}

\section{Introduksi}

Bagian introduksi ini menghadirkan penari anak kecil sebanyak 10 orang, penggunaan penari anak kecil untuk menyimbolkan penari Sintren yang bernama Ade Nuriya sesungguhnya berusia 16 tahun. Adegan ini diwujudkan dengan 10 penari anak-anak menari dengan motif gerak keupat. dengan pola lantai lingkaran dan satu penari sebagai tokoh menari di dalam lingkaran.

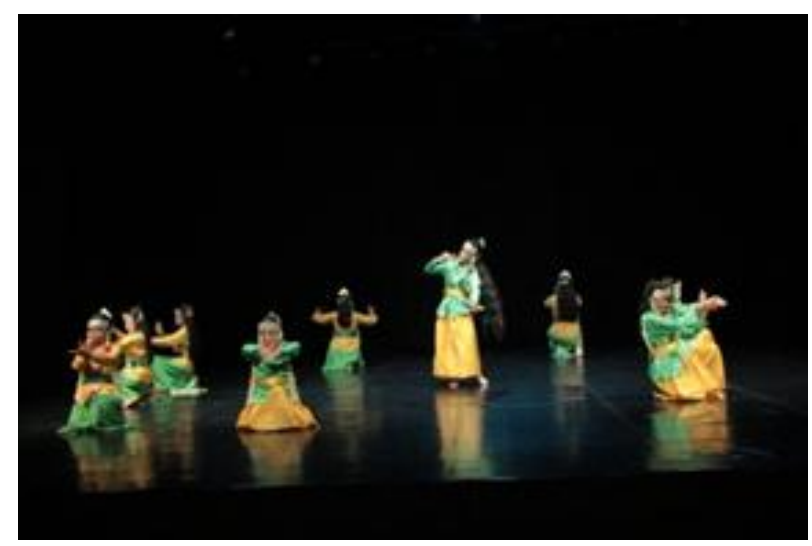

Gambar 6. Pola lantai penari anak-anak pada adegan introduksi. (doc. Ari Kusuma. 2017)

\section{Adegan satu}

Di dalam adegan satu penata ingin memperkenalkan bagaimana motif-motif gerak gaya Indramayu, selain itu menyimbolkan bagaimana perjalanan Ade Nuriya sebagai penari Sintren tidak mudah banyak rintangannya tetapi Ade Nuriya menjalankannya dengan ikhlas seperti tidak ada beban. Hal ini disimbolkan dengan gerakan yang atraktif dan didukung dengan ekspresi bahagia. Pada adegan ini kostum rok digunakan sebagai properti menari. Pergantian dari adegan ini menuju adegan selanjutnya 4 penari dewasa masuk membawa kurungan dan 3 penari anak-anak masuk dengan membawa 3 kurungan.

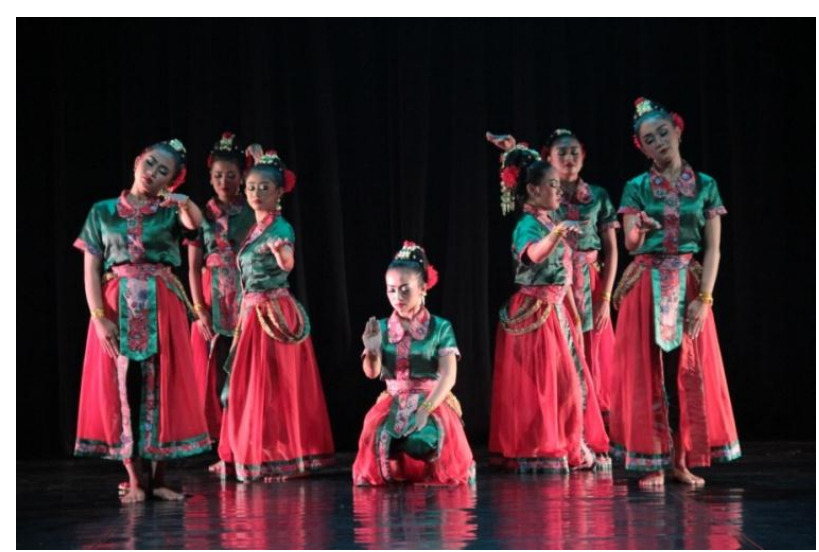

Gambar 7. Sikap penari pada adegan satu awal ketika melakukan motif gerak khusuk. ( doc. Ari Kusuma. 2017 )

\section{Adegan dua}

Adegan dua penata menggunakan kurungan ayam sebagai properti, karena dalam kesenian sintren kurungan ayam sebagai properti yang mutlak digunakan. Pada adegan 
ini penggunaan kurungan ayam digunakan tidak sebagai fungsi yang sebenarnya. Penata mencoba merubah sedikit bentuk kurungan ayam yang biasanya hanya lingkaran.

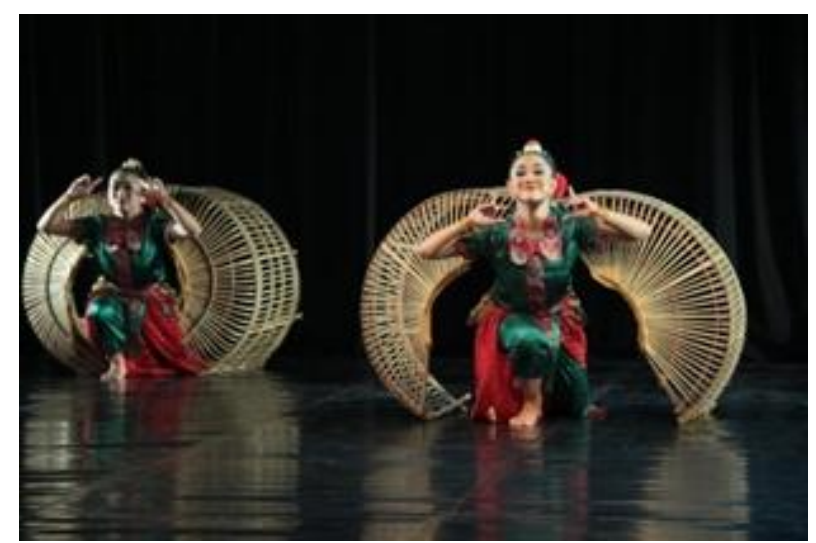

Gambar 8. Sikap penari dengan properti kurungan. ( doc. Ari Kusuma. 2017 )

\section{Adegan tiga}

Pada adegan tiga merupakan gambaran proses penari rela seolah-olah tubuhnya dirasuki oleh roh, motif gerak yang dilakukan yakni keupat, motif gerak inilah yang biasa dilakukan oleh penari sintren ketika trance. Lagu Turun-turun Sintren yang biasanya dijadikan media pemanggilan roh, pada adegan 3 juga menggunakan lagu Turun-turun Sintren sebagai musik pengiring pada adaegan 3 ,

Penari bergerak dengan mata tertutup dan menggunakan kacamata. Pada adegan ini terdapat penambahan kain yang menutupi kurungan, kain penutup terbagi menjadi 3 warna yakni warna putih sebagai simbol dari kesucian, warna merah sebagai simbol dari keberanian penari Sintren mengambil langkah menjadi penari Sintren, kemudian warna emas melambangkan keagungan dari roh bidadari yang merasuki penari Sintren.

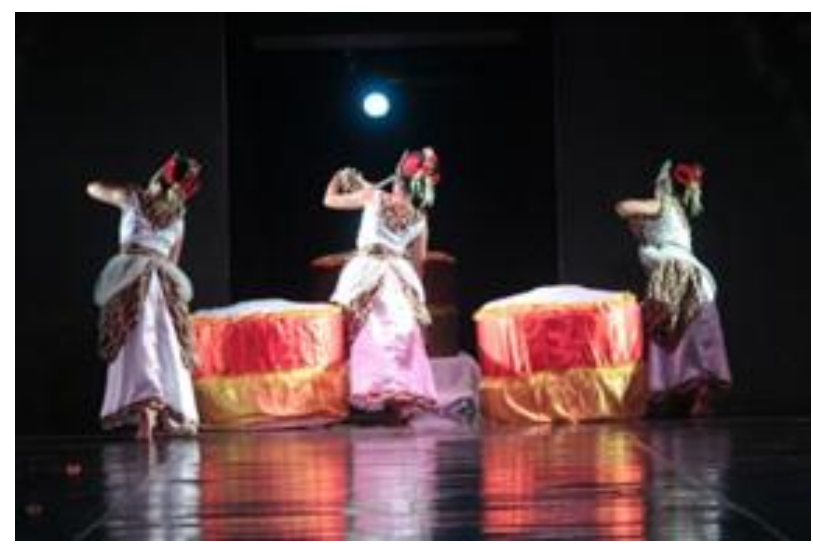

Gambar 9. Salah satu sikap ketika penari melakukan motif gerak keupat. ( doc. Ari Kusuma. 2017)

5. Akhir

Adegan ini penari di tuntun untuk ikhlas bergerak tanpa ada unsur paksaan, maka dari itu penata sepenuhnya menyerahkannya kepada penari. Kemudian diakhir adegan, penari dilempar koin dari segala sisi, lemparan ini dilakukan acak dan terus-menerus sebagai simbol untuk penyadaran kembali penari sintren dan keluarnya roh bidadari dari tubuh sang penari sintren.

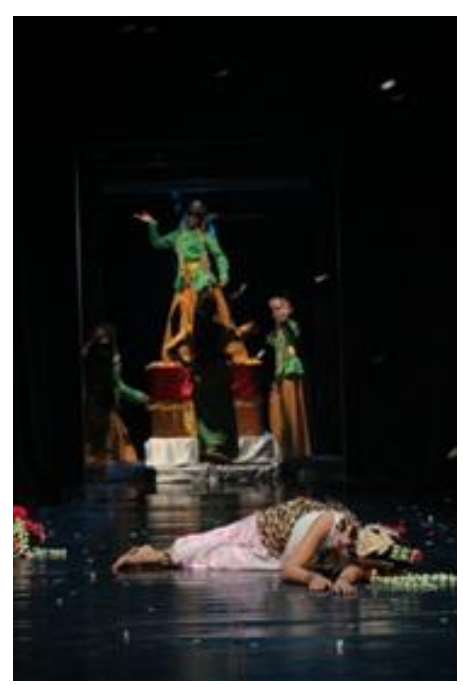

Gambar 10. Adegan penari anak-anak di bagian akhir. (doc. Ari Kusuma. 2017) 


\section{PENUTUP}

Proses penciptaan kali ini penata tari mendapatkan banyak sekali pengalaman. Dalam waktu dan tempat yang sama, berproses untuk membuat sebuah karya tari diri kita menjadi seorang koreografer, Manager dan Penonton. Berproses dengan banyak orang yang memiliki karakter yang berbeda-beda bukanlah sesuatu yang mudah. Selain kita harus menyamakan rasa dalam berproses, kita harus mengerti waktu satus ama lain agar tidak terjadi salah paham. Pada proses penciptaan Tugas Akhir ini tidak sedikit mengalami kendala yang dihadapi dari mulai awal mencari penari, penari yang pada saat latihan jarang lengkap karena memiliki kesibukan, belum lagi di akhir tahun waktu banyak dibuang karena banyak perayaan hari besar, selain itu ada juga penari yang tiba-tiba mengundurkan diri sehingga harus mencari penggantinya dengan cepat, namun hal itu tidak menjadi alasan untuk sebuah proses menjadi terhenti, justru dapat menjadi sebuah tantangan.

Karya tari ini diciptakan berasal dari pengalaman penata melihat kesenian sintren, ketertarikan penata ketika melihat pertunjukan sintren tertuju pada penari sintren, bagaimana perasaan penari sintren ketika tubuhnya harus dirasuki roh. Maka dari itu karya ini mengambil tema tentang keikhlasan penari Sintren yang berbeda-beda dan di beri judul Tumurune Hapsari. Tipe tari pada karya ini termasuk kedalam tipe tari dramatik. Cara penyajian pada karya tari ini menggunakan mode penyajian representasional dan nonrepresentasional (simbolik). Pencarian gerak penata menggunakan beberapa motif pada tari Randu Kentir yang kemudian dikembangkan.

Menghargai proses adalah kunci kesuksesan dari sebuah karya, karena orang hebat bukanlah orang yang pintar tetapi orang yang ingin dan bersedia berproses.

\section{DAFTAR SUMBER ACUAN}

\section{A. Sumber Tertulis}

Effendi, Irwansyah, 2014, Spiritualitas, Jakarta: Gramedia pustaka pusat.

Hadi, S , Dkk, 2011, Mula Bukane Kesenian Sintren, Jawa Tengah: Taufik.

Darmaprawira, Sulasmi, 2002, Warna, Bandung: ITB.

Mahastra, Dyah, dkk,2011,Tari Seni Pertunjukan Ritual dan Tontonan, Yogyakarta: Program Pascasarjana ISI Yogyakarta.

Martono, Hendro, 2008, Sekelumit Ruang Pentas, Yogyakarta: Cipta Media.

2010, Mengenal Tata Cahaya Seni Pertunjukan, Yogyakarta: Cipta Media. 


pertunjukan
Yogyakarta: Cipta Media.

Hadi, Y.Sumandyo.2003. Aspek-aspek Dasar Koreografi Kelompok. Yogyakarta: Cipta Media.

2011. Koreografi BentukTeknik-Isi. Yogyakarta: Cipta Media.

Hastuti Sri, 2013, Sawer: Strategi Topeng Dalam Menggapai Selera Penonton, Yogyakarta: Cipta Media.

Hersapandi, 2014, Ilmu Sosial dan Budaya, Yogyakarta: Badan Penerbit ISI Yogyakarta.

Hawkins, Alma M. 2003. Moving From Within: A New for Dance Making, dimana: penerbit. Diterjemahkan ke bahasa Indonesia dengan judul Bergerak menurut Kata Hati. 2003. Jakarta: Ford Foundation dan Masyarakat Seni Pertunjukan Indonesia.

N.A kel.keturunan Aria Wiralodra, 2016, Sejarah Indramayu, Indramayu: Kainoe Publishing.

Smith, Jacqueline, 1985, Komposisi Tari: Sebuah Pertunjukan Praktis Bagi Guru, terjemahan Ben Suharto, Yogyakarta: Ikalasti.

Soemantri, Rd Tjetje, 2007, Tari Sunda: 19401965. Bandung pusbitari press.

Sumardjo, Jakob, 2003, Simbol-simbol Artekaf Budaya Sunda, Bandung: Kelir.

Wahidin, Dede, dkk, 2005, DESKRIPSI KESENIAN CIREBON, Bandung: Asisten Deputi Urusan Kesenian Deputi Bidang Seni dan Film kementrian Kebudayaan dan Pariwisata.
Yudhistira, Dianing Widya, 2007, Sintren, Jakarta: Grasindo.

\section{B. Discografi}

Dokumentasi tari "Cry Jailolo" karya Eko Supriyanto.

Dokumentasi tari "Randu Kentir" oleh Kelurga Pelajar dan Mahasiswa Indramayu.

Dokumentasi "Sintren" oleh penata. Dokumentasi tari "Topeng Klana" Oleh Kaniri.

\section{Webtografi}

http://www. youtube.com 
Fetri Ana Rachmawati (JURNAL TUMURUNE HAPSARI)

JOGED

ISSN: $1858-3989$ 